удк 369.542(477)

\title{
ПЕРСПЕКТИВИ РОЗВИТКУ НЕДЕРЖАВНОГО ПЕНСІЙНОГО ЗАБЕЗПЕЧЕННЯ В УКРАЇНІ
}

\section{PROSPECTS OF THE DEVELOPMENT OF NON-STATE PENSION PROVISION IN UKRAINE}

\author{
Марич Максим Григорович \\ кандидат економічних наук, доцент, \\ Чернівецький національний університет імені Юрія Федьковича \\ ORCID: https://orcid.org/0000-0002-5400-0503 \\ Шупер Антон Сергійович \\ студент, \\ Чернівецький національний університет імені Юрія Федьковича \\ ORCID: https://orcid.org/0000-0001-5323-4845
}

Marych Maksym, Shuper Anton

Yuriy Fedkovych Chernivtsi National University

\begin{abstract}
Стаття присвячена актуальним питанням розвитку системи недержавного пенсійного забезпечення в Україні. У роботі визначено, що можливість індивідуалізації процесу накопичення коштів на потреби пенсійного забезпечення, підвищення розміру середньої пенсії в державі та часткового розв'язання проблеми необхідності здійснення значних бюджетних витрат на фрінансування десріцитного Пенсійного фонду України обумовлює перспективність розвитку недержавних пенсійних фрондів (НПФ) в межах національної пенсійної системи. Здійснено оцінку основних показників фрунціонування НПФ в Україні, а також досліджено найпоширеніші інвестиційні активи у структурі портоеля НПФ України протягом останніх років. Визначено заходи, що забезпечать розширення географії та підвищення результативності фрункціонування мережі НПФ в Україні.

Ключові слова: недержавне пенсійне забезпечення, пенсійні внески, пенсійні активи, пенсійні заощадження, НПФ, пенсійні виплати.
\end{abstract}

Статья посвящена актуальным вопросам развития системы негосударственного пенсионного обеспечения в Украине. В статье установлено, что возможность индивидуализации процесса накопления средств на нужды пенсионного обеспечения, повышение размера средней пенсии в государстве и частичного решения проблемы необходимости осуществления значительных бюджетных расходов на фринансирование десрицитного Пенсионного фронда Украины определяет перспективность развития негосударственных пенсионных фондов (НПФ) в рамках национальной пенсионной системы. Осуществлена оценка основных показателей фрункционирования НПФ в Украине, а также исследованы наиболее распространенные инвестиционные активы в структуре портфреля НПФ Украины в течение последних лет. Определены мероприятия, которые обеспечат расширение географии и повышение результативности фуунционирования сети НПФ в Украине.

Ключевые слова: негосударственное пенсионное обеспечение, пенсионные взносы, пенсионные активы, пенсионные сбережения, НПФ, пенсионные выплаты.

The article is devoted to topical issues of development of the system of non-state pension provision in Ukraine. In the article we established that the possibility of individualizing the process of accumulating funds for the needs of pension provision, increasing the size of the average pension in the state and partially solving the problem of the need to realize significant budgetary expenditures to finance the deficit of Pension Fund of Ukraine determines the prospects for the development of non-state pension funds (NPFs) within the framework of the national pension system. The assessment of the main indicators of the functioning of NPFs in Ukraine in recent years has been carried out. The most common investment assets in the portfolio of NPFs of Ukraine in recent years have been investigated. In the article we described significant obstacles to the full functioning of NPFs, such as: obsolescence and limited legal regulation, insufficient income of citizens, too low level of financial literacy and trust of Ukrainians. In the article we identified measures that will ensure the expansion of the geography and improvement in the effectiveness of the functioning of the NPF network in Ukraine. They include: creation of the State Guarantee Fund citizens' pension contributions to NPFs; increasing the level of transparency of NPFs and strengthening the protection of the rights 
of their participants; improving and modernizing the general ats, approved by law on risk management of NPFs; carrying out informational measures to increase the number of Ukrainians that are participants of NPFs; abolition of taxation of payments from NPFs upon reaching retirement age by participants of such funds; approval of tax benefits for legal entities that will establish NPFs with a total number of participants exceeding 2,000 people; ensuring the overall development of the financial market of Ukraine to create additional financial instruments, in which NPFs can invest in order to further diversify investments and increase the profitability; de-shadowing of residents' incomes; improve the living standards of Ukrainians and so on.

Keywords: private pension provision, pension contributions, pension assets, pension savings, NPFs, pension payments.

Постановка проблеми. На сучасному етапі розвитку економіки нашої держави через демографрічну кризу і старіння населення весь час зростає навантаження на Пенсійний фронд України (ПФУ). Вже не перший рік бюджет ПФУ є десріцитним, уряд вимушений збільшувати обсяги коштів на його покриття, що, у свою чергу, створює додаткове навантаження на Державний бюджет і ускладнює можливості забезпечення належного рівня життя населення. Чисельність працездатного населення протягом останніх років стабільно скорочується, а кількість осіб, що досягли пенсійного віку, натомість, зростає. Така ситуація і є, на сьогодні, об'єктивним негативним чинником, що стримує зростання рівня уже призначених пенсій та знижує розмір пенсій для майбутніх отримувачів.

Пенсійне забезпечення громадян в Україні $€$ однією 3 найскладніших та соціально гострих проблем. Середній розмір призначеної пенсійної виплати у другому кварталі 2021 року складав 3778,78 грн., що становить трохи більше реального прожиткового мінімуму для осіб, що втратили працездатність (3658,93 грн.) [5, с. 1; 3, с. 1].

Конституцією України гарантовано право на забезпечену старість кожного громадянина України, зокрема ст. 46 цит. «...громадяни володіють правом на соціальний захист, складовою якого виступає право на забезпечення їх у разі повної, часткової або тимчасової втрати працездатності, втрати годувальника, безробіття 3 незалежних від них обставин, а також у старості...» [2, с. 1].

Усі розвинені держави світу реалізують комплексну політику, що сприяє створенню якісної системи соціального забезпечення, зниженню ймовірності соціальних конфрліктів і потрясінь, що виникають у суспільстві, тощо. Головним завданням урядів сучасності $€$ гарантування стабільного соціального захисту населення, складовим елементом якого $є$ пенсійне забезпечення.

Зарубіжний досвід демонструє, що НПФ ефрективно виконують роль потужних інститу- ційних інвесторів. Окрім розв'язання соціальних проблем, вони фрормують джерела внутрішніх інвестиційних ресурсів для економіки держави. Можливість індивідуалізації процесу накопичення коштів на потреби пенсійного забезпечення, підвищення розміру середньої пенсії в державі та часткового розв'язання проблеми необхідності здійснення значних бюджетних витрат на фрінансування дефіцитного Пенсійного фонду України визначає перспективність розвитку НПФ в межах національної пенсійної системи [9, с. 204-205].

Саме тому, актуальним на сьогодні стає дослідження особливостей фрункціонування української системи недержавного пенсійного забезпечення (далі - НПЗ).

Аналіз останніх досліджень і публікацій. У рамках обраної нами проблематики фрункціонування системи НПЗ, зокрема у частині сучасного стану та перспектив діяльності недержавних пенсійних фондів, здійснюють власні дослідження такі вітчизняні вчені: Брус С., Вишивана Б., Владика Ю., Мамчур В., Приймак І., Сокоринський Ю., Ткаченко Н., Федина В., О. Неліпович, А. Рибальченко, Т. Сальникова, А. Ткач, А. Бахмач, В. Никитенко, В. Нагорний та ін. Особливу увагу вони приділяють розкриттю особливостей НПЗ; обґрунтуванню соціальної значущості та стратегічної необхідності добровільної недержавної системи пенсійних заощаджень; окресленню проблем, які стримують розвиток НПЗ в Україні; визначенню стратегії, яку застосовують вітчизняні НПФ при інвестуванні пенсійних активів; аналізу нормативноправової бази НПФ.

Також у свої роботах теоретичні питання створення та розвитку недержавних пенсійних фрондів у різних країнах аналізували такі зарубіжні вчені як С. Едвардс, Д. Корсетті, Дж. Стадманн і Ф. Стеварт.

Виділення невирішених частин загальної проблеми. На нашу думку, в умовах перманентного зростання дефіциту коштів для фрінансування пенсійних виплат та існування реальної загрози неспроможності держави гарантувати пенсійне забезпечення грома- 
дян, питання шляхів реформування та модернізації вітчизняної пенсійної системи залишаються неповністю проаналізованими.

Формулювання цілей статті. Метою статті $€$ дослідження поточної ситуації та визначення основних перспектив розвитку системи НПЗ в Україні.

Для досягнення встановленої мети необхідним $€$ вирішення наступних завдань:

- розкрити економічну сутність та класифрікувати види НПФ;

- з'ясувати фонкціональну роль та місце НПФ у структурі пенсійної системи;

- проаналізувати поточний стан українського НПЗ;

- сфрормулювати перспективи розвитку НПФ у пенсійній системі України.

Виклад основного матеріалу. НПЗ - це складовий елемент системи накопичувального пенсійного забезпечення, який базується на добровільній участі юридичних та фрізичних осіб в акумуляції пенсійних заощаджень задля одержання учасниками НПЗ додаткових пенсійних виплат. Суб'єктами системи НПЗ є: НПФ; учасники пенсійних фондів; роботодавці - в ролі платників до корпоративних пенсійних фрондів; органи державного регулювання у сорері НПЗ; адміністратори пенсійних фондів; компанії з управління активами (КУА); зберігачі; банківські установи; страхові організації та інші [8, с. 164-167].

НПФ це - юридична особа, створена відповідно до Закону України «Про недержавне пенсійне забезпечення», що має статус неприбуткової організації, метою діяльності якої $€$ винятково нагромадження пенсійних внесків на користь відповідних учасників із наступним керуванням акумульованими фрінансовими ресурсами й здійсненням виплат пенсій [7, с. 1].

До недержавних пенсійних фрондів в Україні належать:

1) відкриті пенсійні фонди, учасниками яких можуть стати будь-які фрізичні особи незалежно від особливостей їхньої професійної діяльності;

2) корпоративні пенсійні фонди, які засновуються юридичними особами-роботодавцями; учасниками таких фондів можуть стати тільки фрізичні особи, які перебувають (перебували) у трудових відносинах із роботодавцями - організаторами й роботодавцями платниками до НПФ;

3) професійні пенсійні фонди, заснувати які можуть об'єднання юридичних осіб-роботодавців та фрізичних осіб, включно із професійними спілками, або фрізичні особи, що об'єднані напрямом своєї профресійної діяльності. Учасниками зазначеного фронду можуть бути винятково фрізичні особи, пов'язані між собою фрахом, затвердженим в його статуті $[7$, c. 1].

Необхідність існування ефективної мережі НПФ підтверджується їх соціально-економічним значенням (рисунок 1).

Важливість НПФ для пенсійної системи та економіки в цілому очевидна. Така особлива

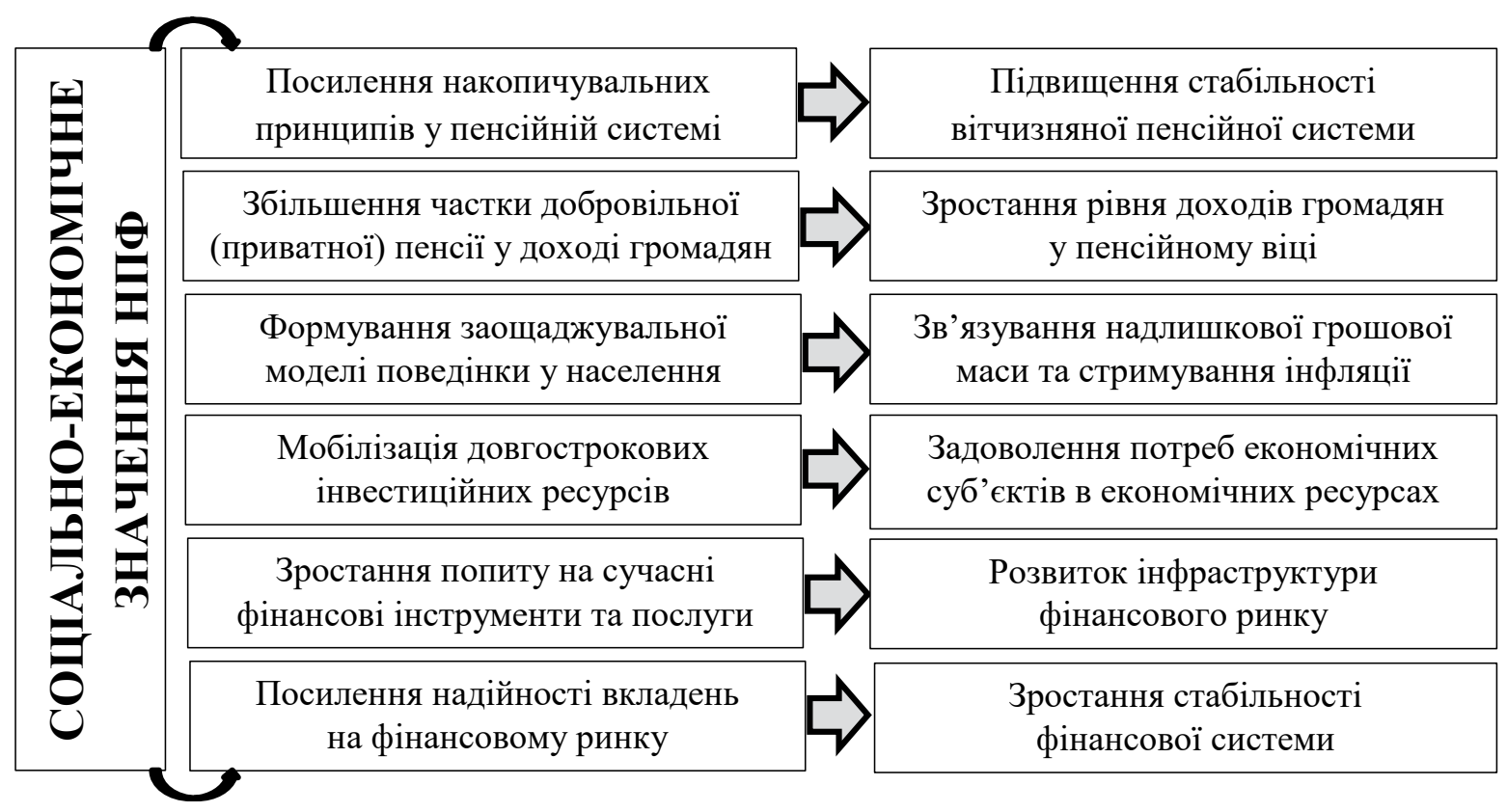

Рис. 1. Комплекс впливу НПФ на економічну систему держави 


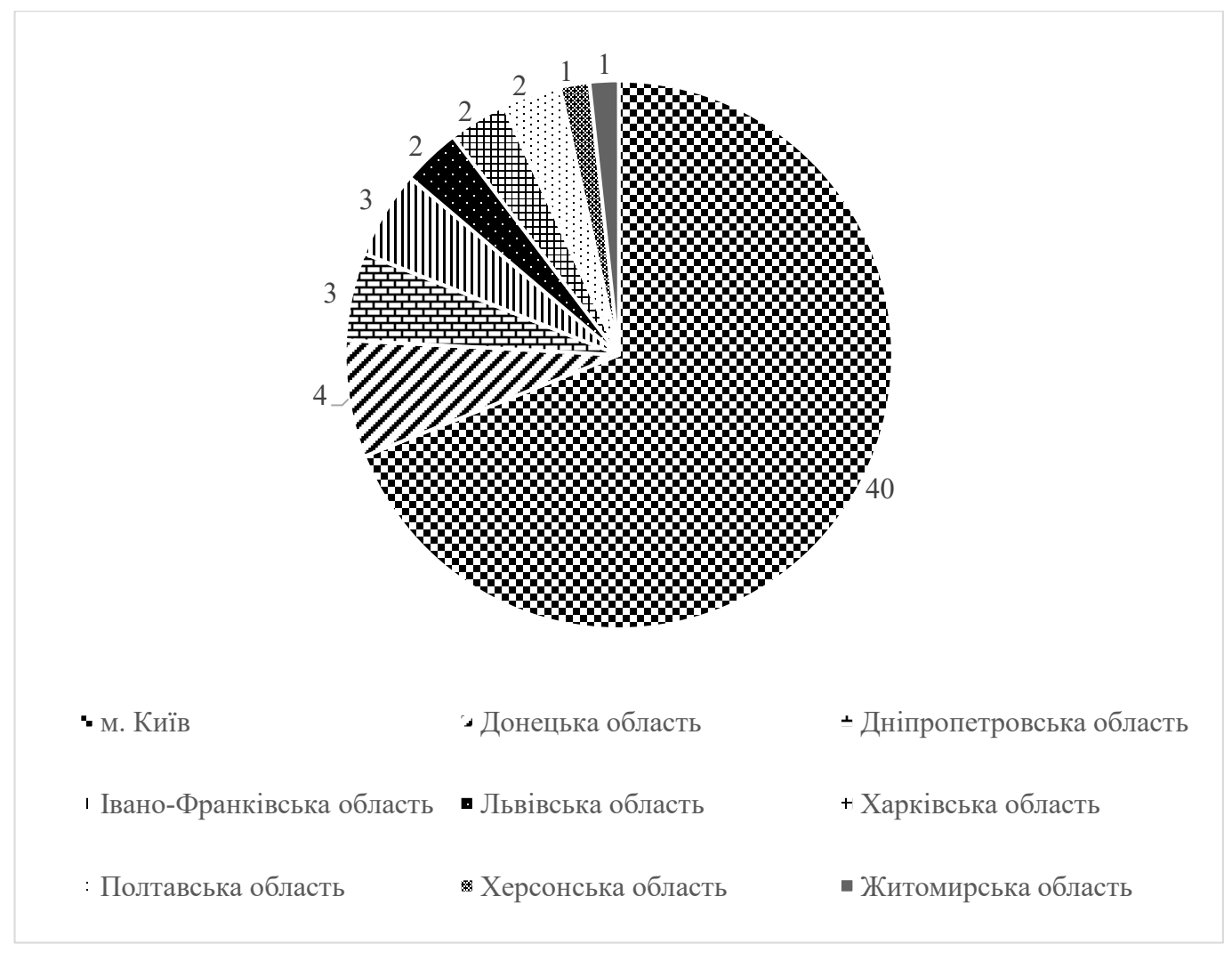

Рис. 2. Територіальний розподіл НПФ на 30.06.2021

Джерело: [4, с. 1]

соціальна-фрінансова установа фрормує додаткові можливості для підвищення рівня матеріальної забезпеченості населення в умовах обмежених можливостей державної пенсійної системи, а також є стимулятором економічного розвитку в країні [1, с. 136-137].

На 30.06.2021 в Україні фрункціонують 58 НПФ, які зареєстровані у 9 областях нашої держави (рисунок 2).

Понад 68,9\% від загальної кількості НПФ на кінець другого кварталу 2021 року зареєстровані у місті Києві. Необхідно відзначити наявність значного рівня нерівномірності та централізації розподілу НПФ по регіонам України. Це пов'язано з історичними особливостями розвитку та існуванням значних відмінностей у соціально-економічному розвитку різних областей нашої держави.

Дослідимо основні показники діяльності НПФ в Україні за період з 30.06.2019 року до 30.06.2021 (таблиця 1).

На основі вищенаведеної статистичної інформації можна зробити висновок про значне зростання обсягу укладених пенсійних контрактів починаючи із 2019 року (на 27\%). Також надзвичайно важливим позитивним для системи НПЗ показником є приріст роз- міру пенсійних внесків саме від фрізичних осіб (на 83,7\% 32019 року). Однак, у структурі пенсійних внесків протягом усього досліджуваного періоду понад 85,5\% складають внески юридичних осіб. Також варто зазначити, що з 2019 року загальна кількість учасників НПФ зросла лише на 3,2\%. Така ситуація відображає більший ступінь розвиненості корпоративних та профеесійних НПФ в Україні, недостатній рівень інформованості та довіри орізичних осіб до системи НПЗ. Ефективність діяльності НПФ можна оцінити за приростом вартості активів та суми інвестиційного прибутку, що складає у порівнянні із 2019 роком $28,3 \%$ та 44,8\% відповідно. Отже, результативність фрункціонування НПФ в Україні зростає хорошими темпами, однак через недостатній приріст кількості учасників та, відповідно, внесків, потенціал системи НПЗ залишається не повністю задіяним.

Протягом перших двох кварталів 2021 року головними напрямками інвестування НПФ були державні цінні папери $(47,2 \%)$, грошові кошти та депозити (36,6\%) (рисунок 3). Це пояснюється недостатнім рівнем розвитку вітчизняного фрондового ринку i, відповідно, обмеженою кількістю фрінансових активів для 
Основні результати функціонування вітчизняних НПФ

Таблиця 1 за період з 30.06.2019 року до 30.06.2021

\begin{tabular}{|c|c|c|c|c|c|}
\hline \multirow[b]{2}{*}{ Показники } & \multirow[b]{2}{*}{$\begin{array}{c}\text { Станом } \\
\text { на } \\
30.06 .2019\end{array}$} & \multirow[b]{2}{*}{$\begin{array}{c}\text { Станом } \\
\text { на } \\
30.06 .2020\end{array}$} & \multirow[b]{2}{*}{$\begin{array}{c}\text { Станом } \\
\text { на } \\
30.06 .2021\end{array}$} & \multicolumn{2}{|c|}{ Темпи приросту, \% } \\
\hline & & & & $\begin{array}{c}\text { станом на } \\
30.06 .2020 \text { l } \\
\text { станом на } \\
30.06 .2019 \\
\end{array}$ & \begin{tabular}{|c|} 
станом на \\
$30.06 .2021 /$ \\
станом на \\
30.06 .2020 \\
\end{tabular} \\
\hline $\begin{array}{l}\text { Кількість укладених пенсійних } \\
\text { контрактів, тис. шт. }\end{array}$ & 72,7 & 81,9 & 92,4 & 12,7 & 12,8 \\
\hline $\begin{array}{l}\text { Загальна кількість учасників } \\
\text { НПФ, тис. осіб }\end{array}$ & 860,8 & 879,9 & 888,3 & 2,2 & 1,0 \\
\hline $\begin{array}{l}\text { Загальна вартість активів НПФ, } \\
\text { млн. грн. }\end{array}$ & 2892,9 & 3392,8 & 3712,9 & 17,3 & 9,4 \\
\hline Пенсійні внески, всього, млн. грн. & 2071,9 & 2268,0 & 2496,7 & 9,5 & 10,1 \\
\hline \multicolumn{6}{|l|}{ у тому числі: } \\
\hline - від фрізичних осіб & 195,9 & 254,7 & 359,8 & 30,0 & 41,3 \\
\hline - від фрізичних осіб-підприємців & 0,2 & 0,3 & 0,3 & 50,0 & 0,0 \\
\hline - від юридичних осіб & 1875,3 & 2012,5 & 2136,0 & 7,3 & 6,1 \\
\hline Пенсійні виплати, млн. грн. & 878,6 & 1029,7 & 1196,2 & 17,2 & 16,2 \\
\hline $\begin{array}{l}\text { Кількість учасників, що } \\
\text { отримали/ отримують пенсійні } \\
\text { виплати, тис. осіб }\end{array}$ & 82,7 & 85,7 & 88,2 & 3,6 & 2,9 \\
\hline $\begin{array}{l}\text { Сума інвестиційного доходу, } \\
\text { млн. грн. }\end{array}$ & 1945,4 & 2457,5 & 2789,5 & 26,3 & 13,5 \\
\hline $\begin{array}{l}\text { Прибуток від інвестування } \\
\text { активів недержавного } \\
\text { пенсійного фронду, млн. грн. }\end{array}$ & 1587,1 & 2035,3 & 2297,5 & 28,2 & 12,9 \\
\hline $\begin{array}{l}\text { Сума витрат, що } \\
\text { відшкодовуються за рахунок } \\
\text { пенсійних активів, млн. грн. }\end{array}$ & 358,3 & 422,2 & 492,0 & 17,8 & 16,5 \\
\hline
\end{tabular}

Джерело: [4, с. 1]

інвестування. Такий стан справ з одного боку, значно знижує середній рівень дохідності внесків в НПФ, однак, водночас, забезпечує вищий рівень захищеності та нижчий рівень ризиковості у діяльності НПФ.

Найбільшими НПФ за кількістю учасників в Україні на 30.06.2021 є: «Магістраль», «Європа», «Емерит-Україна», «ОТП Пенсія». Однак, за чистою вартістю активів та обсягом активів на 1 учасника беззаперечним лідером $\epsilon$ корпоративний НПФ Національного банку України (рисунок 4). Серед відкритих НПФ лідером за кількістю учасників та чистою вартістю активів $€$ НПФ «ОТП Пенсія». Також варто додати, що пряма залежність між кількістю учасників та чистою вартістю активів відсутня, що демонструє фракт більшого розміру пенсійних відрахувань учасників окремих НПФ та більш ефективне управління відповідними НПФ.

Існування чіткої залежності між зазначеними показниками діяльності НПФ та кількістю років їх повнофрункціональної діяльності не встановлено, адже, наприклад: НПФ
Національного банку України зареєстрований у 2007 році, НПФ «Європа» - у 2004 році, НПФ «Магістраль» та «Емерит - Україна» у 2006 році, НПФ «Соціальна перспектива» у 2005 році, НПФ «ОТП-песія» - у 2009 році .

На сучасному етапі розвитку соціальноекономічної системи України існує значна кількість суттєвих перешкод на шляху до повнофрункціональної діяльності НПФ, а саме: застарілість та обмеженість законодавчо-нормативного регулювання, недостатній рівень доходів громадян, занадто низький рівень фрінансової грамотності та довіри [6, с. 121-138]. Заходами, що значно розширять географрію та підвищать результативність фрункціонування мережі НПФ є наступні:

- створення Державного фонду гарантування частини пенсійних внесків населення до НПФ;

- підвищення рівня прозорості діяльності НПФ та посилення захисту прав їх учасників;

- удосконалення та осучаснення загальних положень, затверджених у законодавстві, щодо управління ризиками НПФ; 


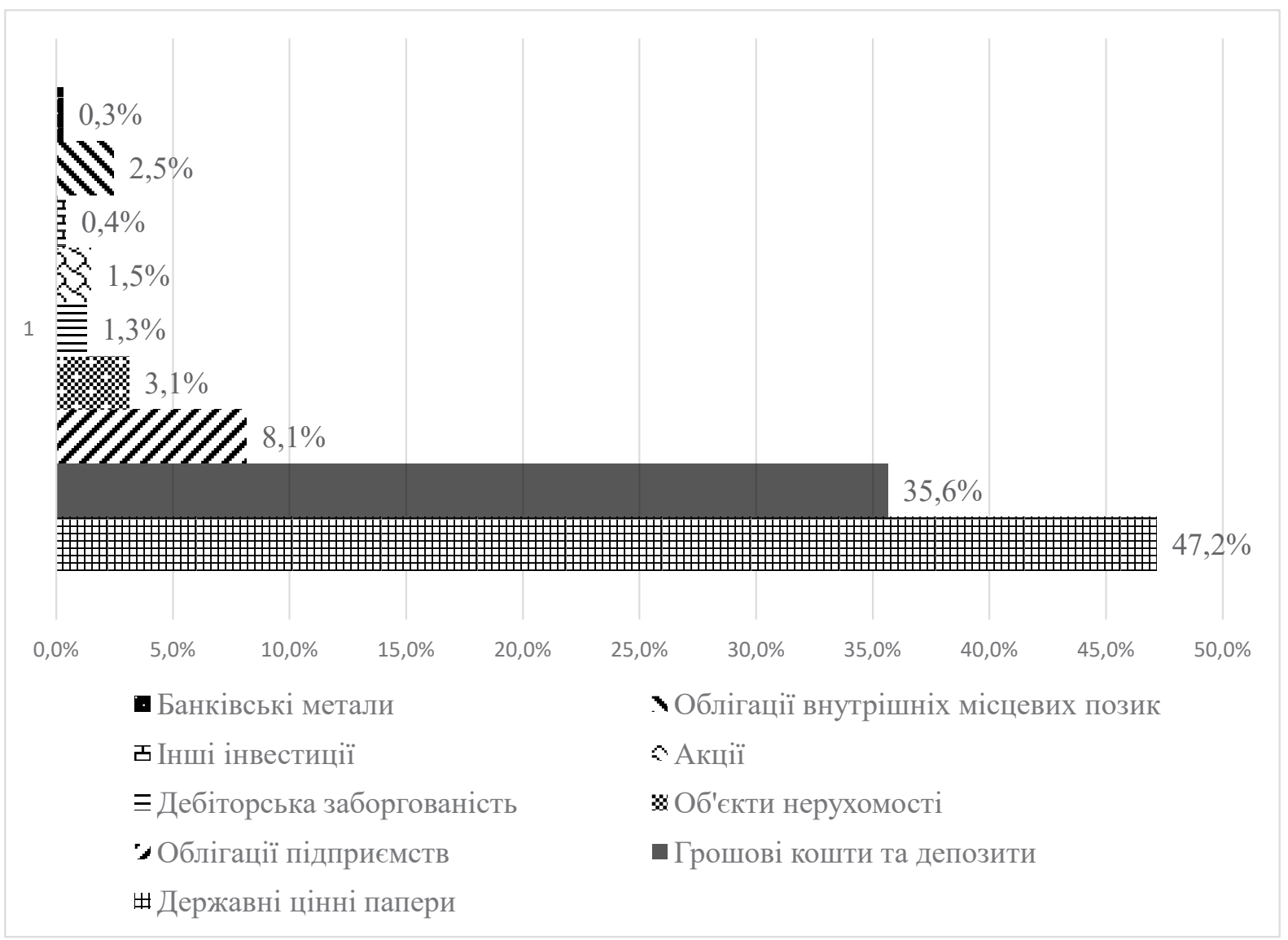

Рис. 3. Основні напрямки інвестування фрінансових ресурсів НПФ в Україні на 30.06.2021 Джерело: [4, с. 1]

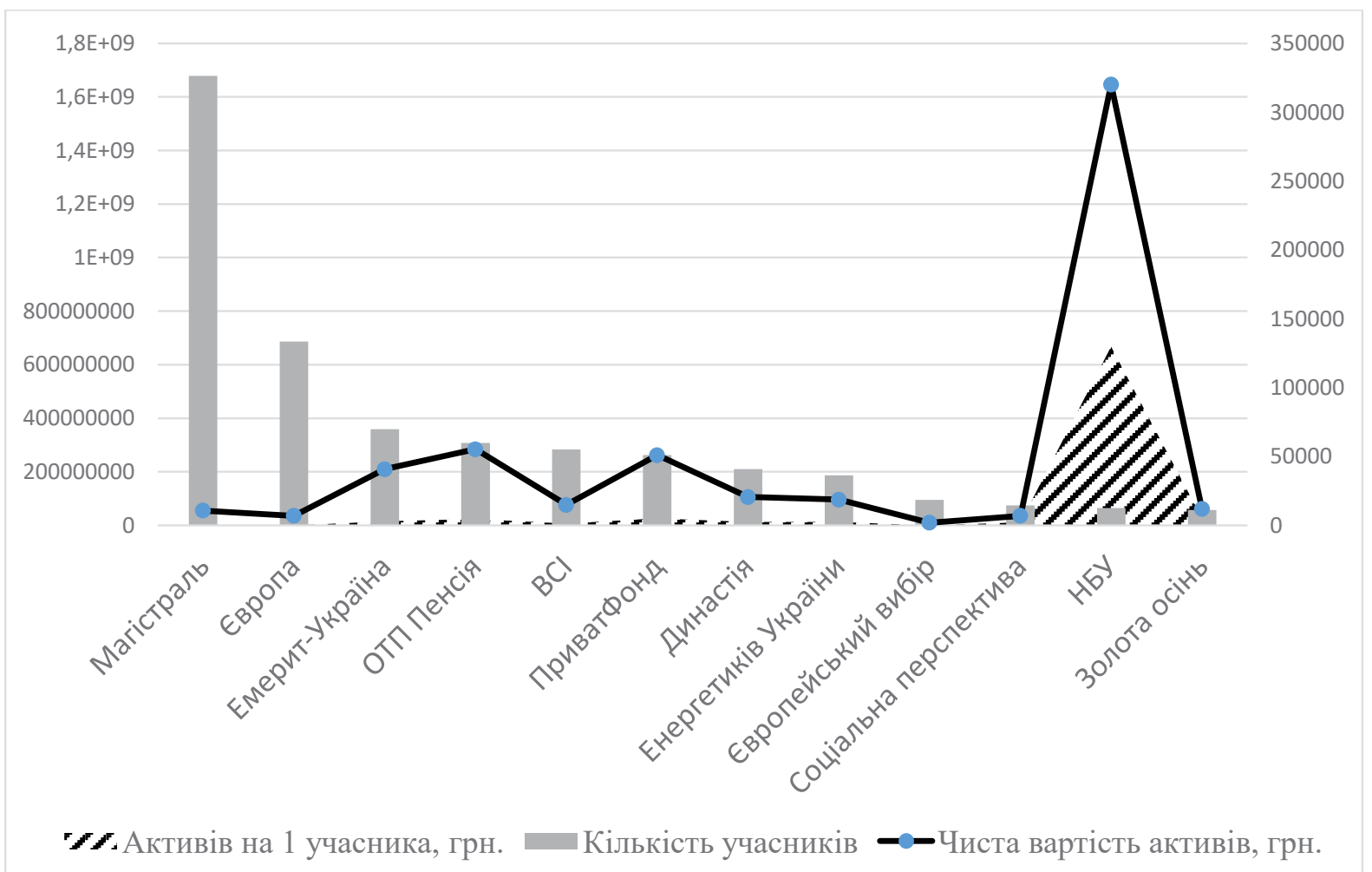

Рис. 4. Топ-12 НПФ в Україні за кількістю учасників на 30.06.2021

Джерело: [4, с. 1] 
- проведення активної інфрормаційнороз'яснювальної роботи та зацікавлення населення щодо участі в системі НПЗ;

- скасування оподаткування виплат з НПФ при досягненні пенсійного віку учасниками таких фрондів;

- затвердження податкових пільг для юридичних осіб, що засновуватимуть НПФ із загальною кількістю учасників, що перевищує 2000 осіб;

- забезпечення загального розвитку фінансового ринку України для розширення фрінансових інструментів, у які можуть інвестувати НПФ 3 метою більшої диверсифрікації вкладень та підвищення їх прибутковості.

Впровадження окреслених рекомендацій забезпечить активізацію процесу акумулювання додаткових та збільшення уже сорормованих фрондів фрінансових ресурсів НПФ, гідний рівень життя громадян на пенсії; сприятиме підвищенню фрінансової стійкості пенсійної системи та пожвавленню соціально-економічного розвитку держави в цілому.

Висновки. На сьогодні в нашій державі система НПФ охоплює недостатню кількість учасників, нерівномірно розподілена за областями України, має низький рівень захищеності від потенційних ризиків та користується недостатнім рівнем інформаційної підтримки, що в цілому потребує розробки та реалізації комплексної програми стимуляції розвитку НПЗ в Україні. Аналізуючи статистичні дані щодо фрункціонування системи НПФ, можна прослідкувати зростання обсягів пенсійних внесків громадян та кількості укладених пенсійних контрактів; існування значного переважання питомої частки пенсійних внесків юридичних осіб у загальній структурі внесків протягом всього досліджуваного періоду; підвищення загальної вартості активів НПФ. Запропоновані рекомендації щодо підвищення результативності фрункціонування мережі НПФ, на нашу думку, позитивно вплинуть на показники діяльності системи НПЗ в Україні. Однак слід зазначити, що ефективність діяльності НПФ у державі знаходиться у прямій залежності не тільки від удосконалення чинної пенсійної системи, а й від підвищення рівня життя населення, детінізації доходів та організації інсрраструктури для розвитку фрінансового ринку у цілому.

\section{СПИСОК ВИКОРИСТАНИХ ДЖЕРЕЛ:}

1. Дзямулич М., Чиж Н. Особливості ффункціонування системи недержавних страхових пенсійних фрондів в Україні. Економічний форум. 2020. № 1. С. 135-140. DOI: https://doi.org/10.36910/6775-2308-8559-2020-1-19

2. Конституція України : Закон від 28 червня 1996 р. № 254к/96-ВР. Верховна Рада України. URL: https://zakon.rada.gov.ua/laws/show/254\%D0\%BA/96-\%D0\%B2\%D1\%80\#Text (дата звернення: 06.10.2021).

3. Ооріційний веб-сайт Міністерства соціальної політики України. URL: https://www.msp.gov.ua/news/12286.html (дата звернення: 06.10.2021).

4. Офріційний веб-сайт Національної комісії з цінних паперів та фондового ринку. URL: https://uww.nssmc.gov.ua/ news/insights/\#tab-5 (дата звернення: 06.10.2021).

5. Офріційний веб-сайт Пенсійного фонду України. URL: https://www.pfu.gov.ua/2147095-dani-pro-serednijrozmir-pensiyi-stanom-na-01-07-2021/ (дата звернення: 06.10.2021).

6. Приймак І., Вишивана Б. Недержавне пенсійне забезпечення в системі соціального захисту населення. Свim фрінансів. 2019. № 3(60). C. 121-138. DOI: https://doi.org/10.32843/bses.55-31

7. Про недержавне пенсійне забезпечення : Закон України від 09.07.2003 № 1057-IV (Редакція станом на 01.07.2021). Верховна Рада України. URL: https://zakon.rada.gov.ua/laws/show/1057-15\#Техt (дата звернення: 06.10.2021).

8. Ріппа М., Шимко Я. Економічна природа недержавних пенсійних фрондів. Економічний вісник університету. 2019. № 41. C. 162-170. DOI: https://doi.org/10.31470/2306-546X-2019-41-162-170

9. Ткаченко Н. Вектори розвитку інвестиційної діяльності недержавних пенсійних фондів в Україні. Проблеми і перспективи економіки та управління. 2019. № 1(17). C. 200-206. DOI: https://doi.org/10.25140/ 2411-5215-2019-1(17)-200-206

\section{REFERENCES:}

1. Dziamulych M., Chyzh N. (2020) Osoblyvosti funktsionuvannia systemy nederzhavnykh strakhovykh pensiinykh fondiv $v$ Ukraini [Features of the functioning of the system of private pension insurance funds in Ukraine]. Ekonomichnyi forum - Economic forum, 1(1), 135-140. DOI: https://doi.org/10.36910/6775-2308-8559-2020-1-19 (in Ukrainian)

2. "Konstytutsiia Ukrainy": Zakon Ukrainy vid 28.06. 1996 roku No 254k/96-BP [The Constitution of Ukraine] (1996, June, 28). Retrieved from: https://zakon.rada.gov.ua/laws/show/254\%D0\%BA/96-\%D0\%B2\%D1\%80\#Text 
3. Ofitsiinyi veb-sait Ministerstva sotsialnoi polityky Ukrainy [Official website of the Ministry of Social Policy of Ukraine]. Retrieved from: https://www.msp.gov.ua/news/12286.html

4. Ofitsiinyi veb-sait Natsionalnoi komisii z tsinnykh paperiv ta fondovoho rynku [Official website of the National Commission on Securities and Stock Market]. Retrieved from: https://www.nssmc.gov.ua/news/insights/\#tab-5

5. Ofitsiinyi veb-sait Pensiinoho fondu Ukrainy [Official website of the Pension Fund of Ukraine]. Retrieved from: https://www.pfu.gov.ua/2147095-dani-pro-serednii-rozmir-pensiyi-stanom-na-01-07-2021/

Pryimak I., Vyshyvana B. (2019) Nederzhavne pensiine zabezpechennia v systemi sotsialnoho zakhystu naselennia [Non-state pension provision in the system of social protection of the population]. Svit finansiv The world of finance, 3(60), 121-138. Retrieved from: http://dspace.tneu.edu.ua/handle/316497/37110 DOI: https://doi.org/10.32843/bses.55-31 (in Ukrainian)

6. Pro nederzhavne pensiine zabezpechennia: Zakon Ukrainy vid 09.07.2003 roku No 1057-IV (Redaktsiia stanom na 01.07.2021) [On Non-state Pension Provision: The Law of Ukraine] (2003, November, 4). Retrieved from: https://zakon.rada.gov.ua/laws/show/1057-15\#Text

7. Rippa M., Shymko Ya. (2019) Ekonomichna pryroda nederzhavnykh pensiinykh fondiv [The economic nature of private pension funds]. Ekonomichnyi visnyk universytetu - University Economic Bulletin, 41, 162-170. DOI: https://doi.org/10.31470/2306-546X-2019-41-162-170 (in Ukrainian)

8. Tkachenko N. (2019) Vektory rozvytku investytsiinoi diialnosti nederzhavnykh pensiinykh fondiv $v$ Ukraini [The vectors of development of private pension funds investment activities]. Problemy $i$ perspektyvy ekonomiky ta upravlinnia - Problems and prospects of economics and management, 1(17), 200-206. DOI: https://doi.org/10.25140/2411-5215-2019-1(17)-200-206 https://doi.org/10.36910/6775-2308-8559-2020-1-19 (in Ukrainian) 